【論文】

\title{
就業構造を反映した通勤者生成原単位
}

\author{
モデルについて
}

\section{WORK TRIP GENERATION MODEL REFLECTING INDUSTRIAL STRUCTURE}

\author{
毛 利 正 光* - 新 田 保 次** \\ By Masamitsu MŌRI and Yasutsugu NITTA
}

\section{1.はじめに}

1960 年以降のモータリゼーションの進展は, 道路交 通計画を交通計画の首座に据えてきた. その際, 需要推 計が計画諸元の基礎デー夕を得るために重要な位置を占 めた. 需要推計手法としては 4 段階推定法が主流を占 め, 分布, 配分と並んで発生交通量推計の研究が原単位 法を中心になされた.

4 段階推定法はよく知られているように, 経済指標, 発生交通量, 分布交通量, 配分交通量の順に推計を行う 方法である．パーソントリップ調查がなされるようにな ってからは分担率の 推計が分布の前後に位置づけられ た. いずれにせよ経済指標を与件とした発生交通量推計 は経済機構と関連しており, その推計技術としての原単 位法に関する研究は経済機構を取り込みながら発展して いく必要があろう.

ところで, 従来, 原単位の分母には, 人口, 世帯, 面 積など，いわば計画するらえで扱いやすい指標がよく使 われてきたが, 2 つの大きな問題点が存在していた. 1 つは，ある時間断面でみると，原単位が都市ごとに変動 する. 2 つは，ある都市に着目しても時間の経過ととも に変わってゆくといら点である．いずれにせよ交通発生 は経済機構と関連しているため, 経済の変動とともに原 単位も変化し, 複雑な現象を呈している. そして 4 段階 推定の中でも立ち遅れた研究分野になっている.

そこで本研究では, 交通の主要な部分を占める通勤交 通住点をあて, 各都市の通勤者の生成原単位の変動構 造を産業構造を介して明らかにすること, そして, 両者 の関係を数学モデルで表わすことを第 1 の目的とし，さ らにこのモデルを原単位の推計モデルとして発展させる ための第 1 歩として, 1970 年, 75 年の原単位モデルの

* 正会員 工博 大阪大学教授 工学部土木工学科

** 正会員 工修 大阪大学助手 工学部土木工学科
比較を通じて時間的一般性の問題について分析した.

\section{2. 従来の研究}

交通量発生に関する研究は, わが国では米谷ほがる 初めとしていくつかみられる. 米谷ほかは, 都市, 区, 用途地域別に車の発生原単位の安定性を調べ, 河上 ${ }^{2)}$ は 原単位法と回帰分析法により, 都市と京都市内の小学校 区を対象に推計式を求めた. 黒川 ${ }^{3), 4)}$ は広島都市圈を対 象に人口, 世帯を単位とした原単位の要因分析を行い, 用途別発生原単位では都市構造指標を説明変数とし, 回 帰分析により推計式を求め, 精度比較も行っている. 青 山号注人口を単位とした発生原単位を交通利便性により 説明し, 清水 ${ }^{6)}$ は原単位の時空間的変動構造の分析と需 要推計一の応用の必要性を訴えた. 杉恵 ${ }^{7)}$ は 2 つの時間 断面で行われたパーソントリップ調查の結果をもとに両 年に共通する推計式を求めようとした. 外国において は, 同様な研究が Kassoff ${ }^{8)}$, Douglas ${ }^{9 / 21}$ ほかに和い てみられる、いずれも推計式の評価はおもに時間断面で なされ，時系列分析は不十分である.

以上の従来の研究の方法を整理すると次のようにな る. 1 つ噔生量を説明変数から直接求める方法で, 回 帰分析により推計式を求めている．2つは発生原単位を 求め, 単位指標を乗ずることにより発生量を求める.こ のとき, 原単位を一定值とする場合と, 原単位を変動す るものと考え, 説明変数との関係を回帰分析により推定 する場合とに分かれる.さらに原単位法に属するものと して category analysis method がある.これは要因を カテゴリー分けし, それぞれのカテゴリーに原単位を与 え, 各カテゴリーに配属される単位数を乗じて発生量を 求めるものである. また, 単位としては人口, 世帯が従 来よく使われてきた.

このような研究成果は交通計画の実現において大きな 力を発揮してきたが，おおむね時間断面での分析にとど 
まっており，時系列分析に耐え得るまで推計式を高める ことが今後必要であると思われる。

\section{3. 通勤者生成原単位の定義とその特徵}

\section{（1）通勤発生現象}

通勤とは空間的に相異なる自宅と職場の移動のことで あり, 通勤者の発生と増加は産業革命以後の産業構造の 変容と密接な関連がある．機械制大工業の出現は農業社 会から工業社会へと産業構造を変え, あわせて生産手段 の集中する都市へと人口移動をうながした. 工業化の初 期においては小経営における住み込み, 工場敷地内での 寮生活にみられるように, 職住の分離は不完全であった が, 工業化の発展が企業の大規模化と雇用者の増大, 地 価の上昇を伴って大規模に展開するにつれ，激しく進行 し, ニュータウンを創るほどにもなっていった．同時に 住居と職場を移動する通勤者が多量に集中的に発生する ようになった.

\section{（2）通勤者生成原単位の定義}

従来, 通勤発生原単位の単位として人口, 世帯が使わ れることが多かった.この原単位を人口 10 万以上の都 市を対象に求め, 都市規模との関係で変動状況をみたの が 図一1，2 である.なお，この原単位の分子は通勤者 数である. 都市規模が小さくなるにつれ都市数が増える とともに, 原単位の変動が大きくなってくる. 人口を単 位とした原単位は 0.24 から 0.42 の閒を変動し, 世帯 を単位としたものは $0.86 〜 1.82$ の間に大きくばらつい ている.

ではなぜ原単位がばらつくのか, 通勤者数/人口の原 単位を例に考えてみよう.人口を仕事をもっているかど らかの視点で 分けると, 就業者と非就業者に 分類され る. そして非就業者には老人, 子供, 失業者などが含ま

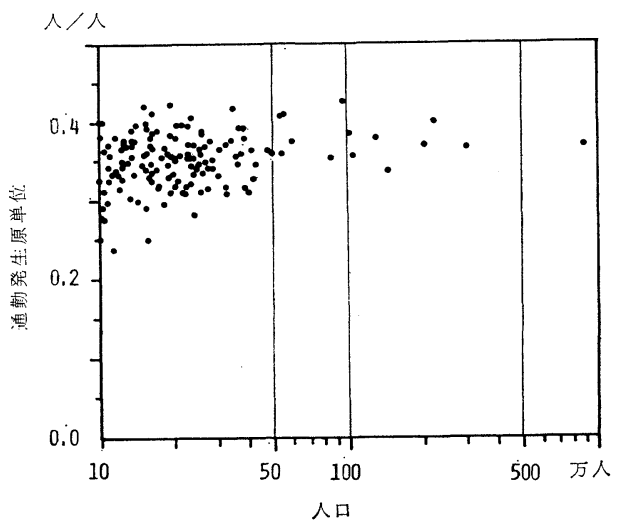

図一1 人口と原単位の関係

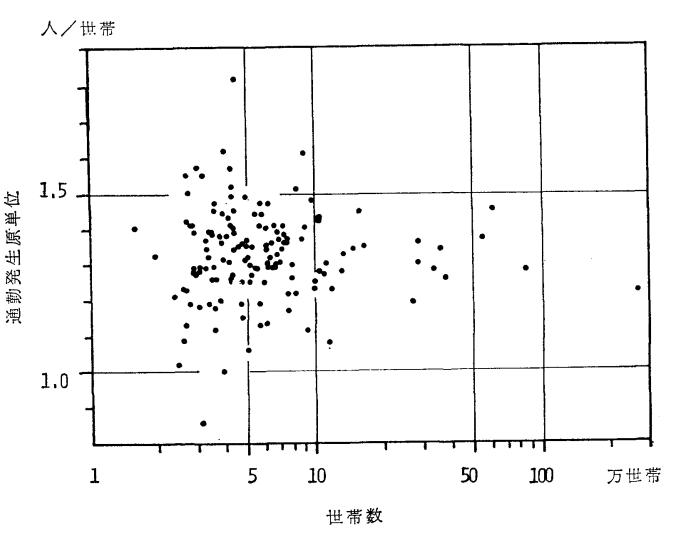

図一2 世帯数と原単位の関係

れる. 人口を単位にとるとこれらの構成比の違いが原単 位の変動要因として入り, 原単位のばらつきを大きくす る原因となる. 分析の手順としてはまず, 就業者の中で の通勤者の割合，つまり就業者を単位とした原単位の変 動原因を探る必要があると思わるれ。そこで本研究では 原単位を次式のように定義し, 通勤者生成原単位と称す ることにした。

通 勤者 $(G)=$ 通勤者数 $(T) /$ 就業者数 $(W)$

データは 1970 年の国勢調查を用い, 通勤者数は各都市 について, 当地に常住する就業者数から自宅就業者数を 減じて求めた. また, 対象都市は人口 10 万人以上 151 都市である。

ここで定義した通勤者生成原単位は, 交通計画上, 通 勤トリップのコントロール・トータル算出のための有用 な情報を与えるものと思われる.つまり, 比較的, 大き なゾーンに対する通勤トリップのコントロール・トータ ル值を推計する際に, 通勤トリップ生成のもとにある通 勤者数を正確に推計し, 続いて, 通勤者の中で休既や病 気などで勤務を休む人や，勤務先を経由せずに，直接， 業務活動に移る人などの通勤行動をとらない人を推計 し, 通勤者の推計值から, この值を減じた推計值をもと に，通勤トリップを推計する方法が考えられるが，この ような場合, ここで定義した原単位による通勤者数の推 計は, 通勤トリップ推計のいわば第 1 段階を占めるとい ら点において有用であろう。また，ここで定義した原単 位を定量化する際に国勢調査で得られた就業者および自 宅以外での就業者数のデータを用いたが，交通計画上， 国勢調查の就業者の定義が妥当か否かについては, 交通 計画の種々のケースに応じて議論されるべきものと思わ れるが, 少なくとも, 通勤トリップのコントロール・ト 一タル值を求める第 1 段階のステップとして位置づけた 範囲においては妥当であると思われる。 


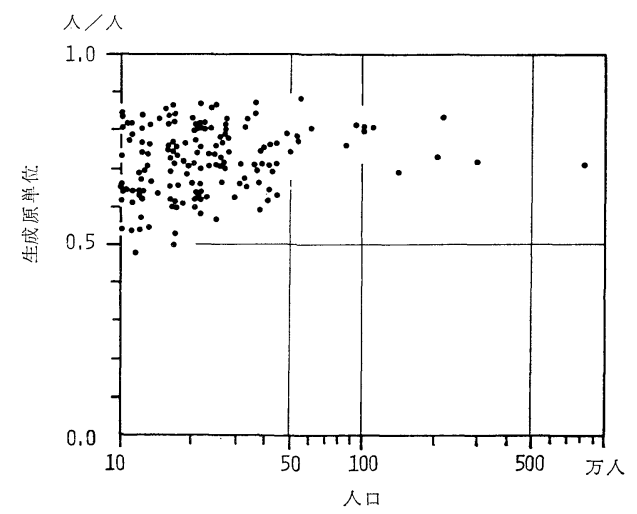

図一3人口と原単位の関係

\section{（3）原単位の変動（人口と原単位）}

式（1）で定義した通勤者生成原単位（以下，原単位 と略称する）を都市別に求め, 人口規模との関係で変動 をみたのが 図一3 である. 人口規模が 小さくなるにつ れ変動が大きくなっている.このことは都市により産業 構造が異なるためであり, 人口が少ない都市ほど多様な 性格をもつためであろら．たとえば，農業人口が比較的 多い都市, 中小零細事業所が多い都市では, 原単位が低 くなり, 大都市周辺の衛星都市では高くなることが想像 される. いずれにせよ, 原単位の変動を都市の産業の内 部構造に立ち入って分析する必要があろう。

\section{（4） $2 \cdot 3$ 次産業就業者構成比亡原単位}

産業構造の高度化は, 1 次産業の衰退, 2 次, 3 次産業 の発展を伴いながら進行しているのが特徴的である.こ のような産業の発達はとりもなおさず通勤者の増加を促 している.このような観点に立てば，人口との関係では うまく説明し得なかった原単位の変動特性を産業構造と の関係である程度説明し得るように思われる. そこで産 業構造を示す代表的な指標として 2,3 次産業就業者構 成比をとり，これらの指標と原単位との関係をみること にした。

表一1 に各産業の就業者構成比 (以下, 構成比と略称 する）と原単位の相関係数を示した. いすれの指標とも 正の相関関係を示すが, 2 次と 3 次産業を合わせた構成 比 $(2+3$ 次産業構成比) との相関が最も高く, 続いて 2 次産業, 3 次産業の順となった. $2+3$ 次産業構成比と

\section{表一1 産業構成比と原単位 の相関係数}

\begin{tabular}{c|c}
\hline 産 業 構 成 比 & 相関係数 \\
\hline $2+3$ 次産業構 成比 & .793 \\
2 次産業 構 成 比 & .512 \\
3 次産業構 成比 & .288 \\
\hline
\end{tabular}

正の相関がよいといらこと は, 裏を返せば 1 次産業構 成比と負の相関がよいこと を示している.また, 2 次， 3 次産業それぞれの構成比 との相関がよくないという

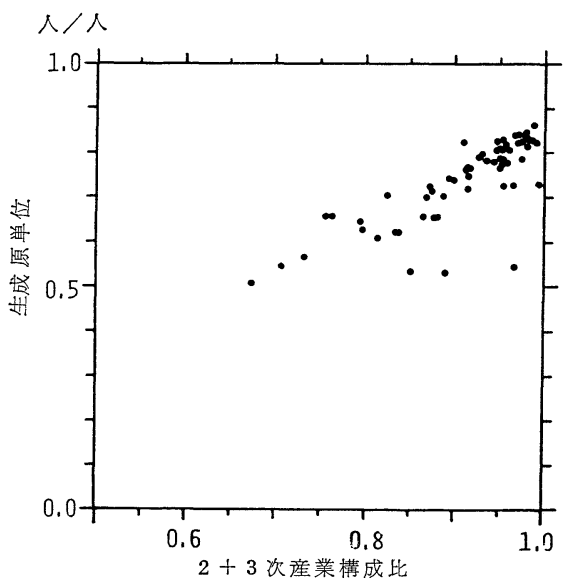

(a) 北海道, 東北, 関東

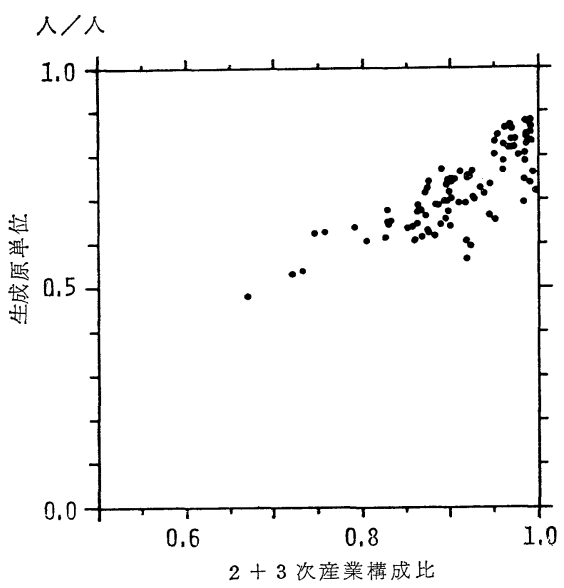

(b) 中部, 近畿, 中国, 四国, 九州

図-4 2+3 次産業構成比と原単位

ことは，両産業とも通勤者を増加させるものでありなが ら，構成比においては一方が高ければ一方が低くなると いった具合に相互に制約しているためであろらと思われ る.

図-4に $2+3$ 次産業構成比と原単位の関係を示した。 平均的な傾向より原単位が低くでる都市には, 桐生, 足 利，一宮といった繊維関係の地場産業をもつ都市や，東 京, 大阪, 名古屋などの大都市が含まれ, 逆に高い都市 には東京, 大阪周辺の 衛星都市が多い. $2+3$ 次産業構 成比により原単位の変動をマクロ的には性格つけられた が，平均的な傾向からはみでる都市がいくつか存在する ように，これらの都市も含めて一般的に説明しょらとす るなら,さらに産業構造に立ち入って分析する必要があ るよらに思われる。 


\section{4. 産業構造を考慮した原単位}

\section{（1）産業別構成比および産業別原単位と原単位との 関係}

原単位の変動については，3. において $2+3$ 次産業構 成比と正の相関関倸にあるといらことが判明したが，さ らにここでは産業構成をもっと詳しく分類し, 原単位の 変動要因について考察する.

それぞれの都市においては産業構造に特殊性があり， 工業都市, 中枢管理都市, 観光都市とかさまざまな性格 を呈している．これらの都市の性格は各産業に従事する 就業者の構成比の差異による場合が多々見受けられる. このような産業構成の差異に加えて, 農業従事者では通 勤者は少なく, 公務員で多いといったように産業によっ て原単位が異なる，そこで，ここでは産業による就業者 構成比, 通勤者生成原単位の違いを考慮して, 式 (1) で 示した原単位とこれら指標との関係を探ることにする。

式（1）で示される原単位 $G$ は，産業分類を考慮する と式（2）となる.

$$
G=T / W=\sum t_{i} / \sum w_{i}
$$

ただし, $t_{i}: i$ 産業の通勤者数 $w_{i}: i$ 産業の就業者数

さらに，産業別通勤者生成原単位 $\left(u_{i}\right)$ を導入すると， $t_{i}$ 注式（3）となる.

$$
t_{i}=u_{i} \cdot w_{i}
$$

また，産業別就業者構成比 $\left(x_{i}\right)$ 江式 (4) となる.

$$
x_{i}=w_{i} / \sum w_{i}
$$

式 (3)，(4) を式 (2) に代入すると，次の式 (5) が得ら れる.

$$
G=\sum u_{i} x_{i} \text { ただし } \sum x_{i}=1
$$

このように原単位 $G$ は, 産業別就業者構成比 $\left(x_{i}\right)$ と 産業別通勤者生成原単位 $\left(u_{i}\right)$ の積の総和で示された。 この式より理解されるように, 産業別通勤者生成原単位 （産業別原単位と略称する）が各都市で一定值をとると しても産業別就業者構成比（産業別構成比と略称する） が変化すれば $G$ は変動することになる.

本研究では産業分類を 1970 年の国勢調查の産業大分 類に従うものとする. この場合，産業は 14 項目に分類 され，統計表では一部統合されて 11 分類となってい る. 分類数が式 (5) を実用式として使う場合，多いと 思われるが，これより分類を少なくすると一般的に認め られている分類は 3 分類しかなく，これでは分析が粗く なるのでここでは 11 分類で分析し, 将来, 簡略化を試

\begin{tabular}{|c|c|c|c|c|c|c|}
\hline & \multicolumn{3}{|c|}{ 原 単 位 } & \multicolumn{3}{|c|}{ 産業構成比 } \\
\hline & $\mu$ & $\sigma$ & $\sigma / \mu$ & $\mu$ & $\sigma$ & $\sigma / \mu$ \\
\hline 農, 林, 狩 併 業 & .064 & .074 & 1.16 & .085 & .068 & .80 \\
\hline 漁, 水 産 養 㱛 業 & .531 & .290 & .55 & .005 & .012 & 2.19 \\
\hline & .903 & .089 & .10 & .002 & .007 & 3.04 \\
\hline 設 & .799 & .057 & .07 & .080 & .017 & .22 \\
\hline 造 & .843 & .084 & .10 & .288 & .105 & .36 \\
\hline 卸 売, 小売 業 & .647 & .084 & .13 & .223 & .040 & .18 \\
\hline 運 輸, 通 信 業 & .893 & .041 & .05 & .034 & .012 & .35 \\
\hline 金融, 保険, 不動産業 & .968 & .016 & .02 & .070 & .019 & .26 \\
\hline 電気, ガス, 水道業 & .993 & .006 & .01 & .007 & .003 & .37 \\
\hline サービス 業 & .719 & .054 & .08 & .165 & .037 & .22 \\
\hline 務 & .992 & .004 & .00 & .039 & .019 & .48 \\
\hline
\end{tabular}
みることにする. 11 分類した場合の産業を 表一2 に示 した.
表一2 産業別原単位および構成比（1970 年）

注) $\mu:$ 平均值, $\sigma:$ 標準偏差

\section{（2）原単位推定式への試み}

式（5）は各都市について，それぞれの固有の数值を 代入することによって恒等的に成り立つものである. ᄂ かし，これは原単位の推定式ではなく，一般的な推定式 をつくるためには，産業別原単位か構成比を各都市につ いて普遍的なものとして決める必要がある．もし，両者 が各都市について一定とおけるならば，原単位 $G$ は一 定となる.しかし，前章での分析から判明したように， こうすると無理が生じてくる.よって産業別原単位か構 成比のどちらか安定しているものを各都市共通のものと して決める必要が生ずる.

そこで, 産業別構成比, 産業別原単位の変動状況を知 るために, 151 都市について, 平均, 標準偏差, 変動係 数を計算した. 表一2 に示したように，産業別構成比の 平均值は製造業が最も高く $29 \%$ ，続いて卸売・小売 22 $\%$ ，サービス $17 \%$, 農・林・狩猟 $9 \%$ となった. 以上 の三者で $68 \%$ を占めた. また標準偏差も製造業が最も 高く $11 \%$ ，続いて農・林・狩猟 $7 \%$ ，卸売・小売 $4 \%$, サービス $4 \%$ となり, 農・林・狩椫の 標淮偏差が高い ことが特徴的である.

一方, 産業別原単位の平均值は電気・ガス・水道, 公 務が 0.99 を超え, 続いて運輸・通信, 鉱が 0.90 以上 となった. 0.8 台は金融・保険・不動産，製造の 2 産業 であり， 0.7 台は建設，サービスである．卸売・小売は 0.65 であり，農・林・狩編は最も低く 0.06 であった。 標準偏差は漁・水産・養殖が最も大きく, 続いて鉱, 製 造, 卸売・小売となり, 小さいのは公務, 電気・ガス・ 水道, 運輸・通信であった.

産業別構成比と原単位の変動を変動係数により比較す ると，農・林・狩猟を除いた全産業において原単位の方 が小さく，変動が少ないことが判明した．農・林・狩編 の場合，原単位そのものが小さいので，この程度の変動 では問題にならない，そこで，産業別構成比は変数と し，産業別原単位を一定值をとる係数とし，式（5）を 
推定式として発展させることにした. また, 発生量推定 の場合, 経済指標を与件とすることにより, 産業別構成 比を変数とするのが妥当である. 表一2 の産業別原単位 の平均值を式 (5) に代入したものを, ここでは原単位モ デルとよぶことにする.そして，この原単位モデルは， 従来の人口などを原単位としたものに比べて, 原単位の 変動構造を産業構造との関連で定式化し, 将来の産業構 成の変化に応じて原単位を予測できるといった点に特徵 がある。

なお，この原単位モデルにより，原単位を推計する際 には, 説明変数である産業別構成比を推計する必要があ る.このことは, とりもなおさず産業別就業者数を予測 することである. 就業者の推計についての研究 ${ }^{13}$ は, 計 量経済学の分野で行われており, 国レベルでは人口推計 に続いて, 精度がよいようである.しかし, 地域, 都市 レベルでの推計は人口と同様に, 国レベルに比較して精 度が落ち, その推計方法は重要な研究対象となってい る. 本モデルでは, このような経済指標を与件としてい るが, 通勤者の推計精度を高めるらえでも, これらの経 済指標の推計精度の向上が必要である.

\section{（3）原単位モデルの適合性}

原単位モデルの適合性を示す指標として, パーセント RMS 誤差を用いることにした. この指標は次式で示さ れる。

$$
\text { 古ーセント 誤差 }=\left(\sqrt{\sum\left(y_{i}-Y_{i}\right)^{2} / n} / \bar{y}\right) \times 100 \%
$$
ただし，

$y_{i}$ : 実際值, ここでは各都市の実際の原単位

\section{$\bar{y}:$ 実際值の平均值}

$Y_{i}$ : 推定值, ここでは各都市の原単位の 推定值

$n$ : データ数, ここでは都市数

1970 年の 151 都市について, 産業別原単位 の平均值（表一2）で係数 $u_{i}$ を表わした原単 位モデルにより推定原単位を求め, パーセント RMS 誤差を計算したところ $7.4 \%$ の誤差とな った. この誤差は比較的小さいと思われ, 推計 モデルとしての妥当性をもっていると思われる が，個別に都市をみると誤差が大きいところも 考えられるので, 原単位の実際值と推計值を図 上にプロットし, この様子を調べることにし た. 図一5,6 に示したように, 推定值が実際 值を大きく上回る傾向のある都市には，足利， 桐生, 甲府, 岐阜, 一宮などの都市があり, 逆 に下回る都市には, 豊中, 吹田, 高槻, 枚方, 茨木などの都市がある. 前者の都市はよく知ら
れているように, 繊維産業を中心とした地方都市であ り, 後者は衛星都市といった特徴をもっている.これら

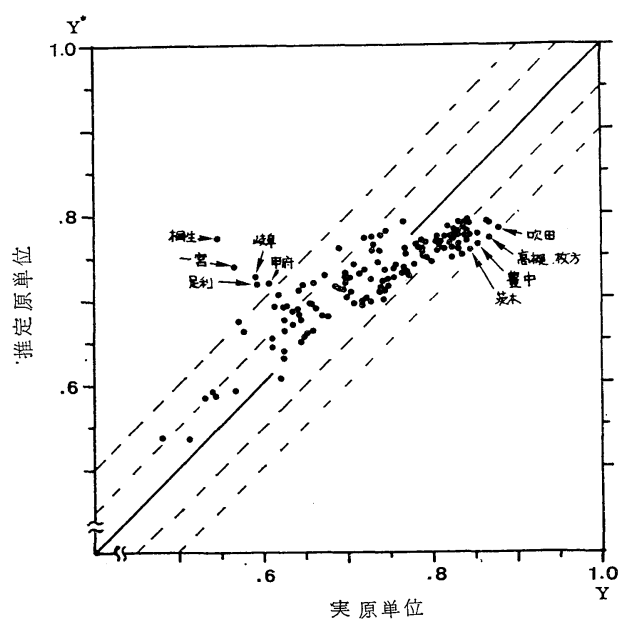

図一5 推定原単位と実原単位の関係（1970 年）

表一3 典型都市の原単位

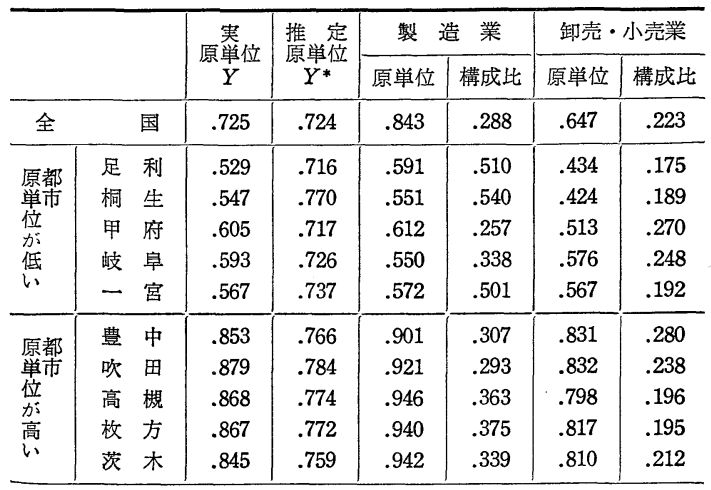

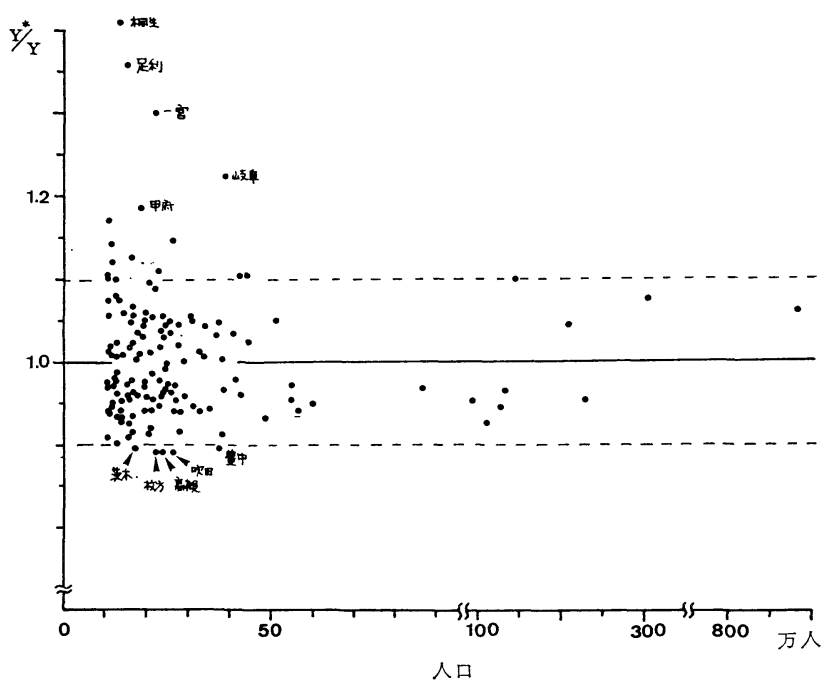

図一6 推定原単位 $\left(\boldsymbol{Y}^{*}\right) /$ 実原単位 $(\boldsymbol{Y})$ の人口規模別 分布 (1970 年) 
の都市について主要産業である製造業, 卸売・小売業の 原単位をみると表一3 に示寸ように，原単位が低い都 市 (足利, 桐生, 甲府など) の製造業, 卸売・小売業の 原単位全国平均に比してかなり低く, 逆に原単位が高 い都市（豊中, 吹田, 高槻など） は高い。推定值が実際 值に適合しない原因には，このように製造業，卸売・小 売業原単位をモデル式で設定した值（全国平均で代表し た）が実態とかけ離れたものになっていることが挙げら れよう。

\section{5. 原単位モデルの時間的安定性}

ここでは前章で定義した原単位モデルの時間的安定性 をみるため, 新たに 1975 年の国勢調査データによる産 業別原単位を求め, 先に求めた 1970 年との比較を通じ て安定性を検討するとともにこれにより原単位モデル の倸数を決定し,モデルの妥当性を検証することとした. この分析に際して, せめて過去 20 年くらいのデータが 欲しかったのであるが，1970 年以前は求めるデータが なかったため, やむを得ず，両年度比較にとどめた。 た， 10 万以上の都市数は 1975 年には 175 都市と 1970 年に比べて 24 都市の増加があった.

\section{（1）原単位の変動}

1975 年で人口 10 万以上の都市について，1970 年の 場合と同様に原単位を求め, その変動を 図一7 に示し た. 1970 年での断面分析において $2+3$ 次産業構成比 と原単位は正の強い相関関係がみられたが，この特徵は 1975 年に㧍いても強く現われた. さらに各都市での原 単位の推移をみると, いずれの都市においても $2+3$ 次 産業構成比の増加とともに原単位も増加した. ただ, 2 +3 産業構成比がほぼ $100 \%$ に近い都市では $2+3$ 次産 業構成比はほとんぞ増加しないにもかかわらず, 原単位 は増加した。 これらのことから, 各都市の原単位は個々 別々にはばらついているものの, 大きくは $2+3$ 次産業 構成比の増加の波に乗って増加し, さらに 2,3 次産業 内においても通勤者の発生程度が高くなっていることが 理解される. な预原単位の平均值は 1970 年 0.725 で あったものが 1975 年では 0.773 と 0.048 増加し, $2+$ 3 次産業構成比の平均值も $91.0 \%$ から $93.8 \%$ 几と増 加した.

\section{（2）産業別原単位の時間的安定性}

1975 年の産業別原単位と産業別構成比を 表一4 亿示 した. 変動係数は全産業において原単位の方が小さくな った. 表一5 に 1970 年との比較を示したが，これでわ かるように, 原単位は建設業, 運輸・通信, 電気・ガ

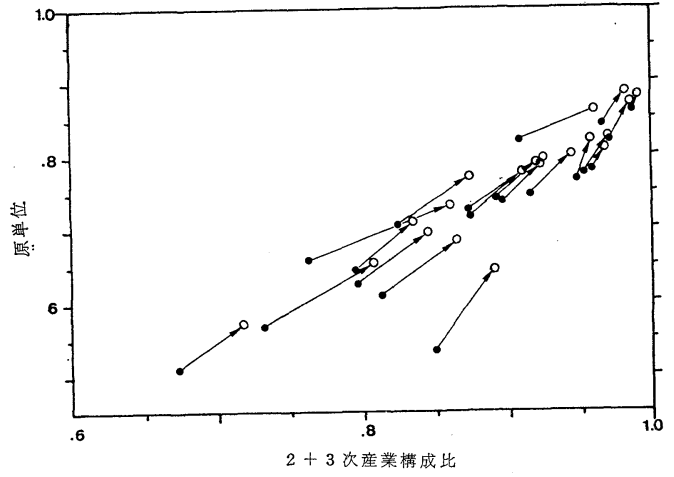

(a) 北海道, 東北

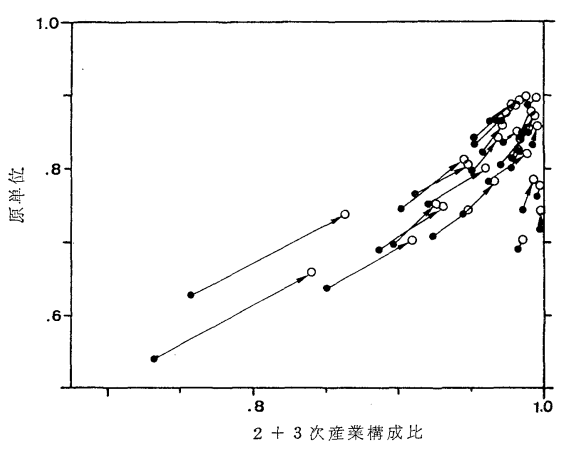

(b) 近畿

図一7 原単位の 70 年から 75 年への推移

表一4 産業別原単位および構成比（1975 年）

\begin{tabular}{|c|c|c|c|c|c|c|}
\hline & \multicolumn{3}{|c|}{ 原 単 位 } & \multicolumn{3}{|c|}{ 産業構成比 } \\
\hline & $\mu$ & $\sigma$ & $\sigma / \mu$ & $\mu$ & $\sigma$ & $\sigma / \mu$ \\
\hline 農, 林, 狩 猟 業 & .137 & .097 & .71 & .058 & .049 & .85 \\
\hline 漁, 水産養殖 業 & .621 & .292 & .47 & .004 & .010 & 2.50 \\
\hline 鉱 & .913 & .079 & .09 & .002 & .005 & 2.50 \\
\hline 設 & .789 & .070 & .09 & .090 & .017 & .19 \\
\hline 製 & .862 & .097 & .11 & .268 & .093 & .35 \\
\hline 卸 売, 小売 業 & .701 & .086 & .12 & .239 & .037 & .16 \\
\hline 運輸, 通信 業 & .906 & .055 & .06 & .041 & .014 & .34 \\
\hline 金融, 保険, 不動産業 & .960 & .041 & .04 & .069 & .016 & .23 \\
\hline 電気, ガス, 水道業 & .984 & .060 & .06 & .007 & .002 & .29 \\
\hline サーピス業 & .783 & .062 & .08 & .178 & .033 & .19 \\
\hline 公 & .985 & .054 & .06 & .041 & .018 & .44 \\
\hline
\end{tabular}

表一5 産業別原単位と構成比の 70 年, 75 年比較

\begin{tabular}{|c|c|c|c|c|c|c|}
\hline & \multicolumn{3}{|c|}{ 原 単 位 } & \multicolumn{3}{|c|}{ 産業構成比 } \\
\hline & 70 年 & 75 年 & $75-70$ & 70 年 & 75 年 & $75-70$ \\
\hline 農, 林, 狩 㹰 業 & .064 & .137 & .083 & .085 & .058 & -.027 \\
\hline 漁, 水産養殖 業 & .531 & .621 & .090 & .005 & .004 & -.001 \\
\hline 業 & .903 & .913 & .010 & .002 & .002 & .000 \\
\hline 業 & .799 & .789 & -.010 & .080 & .090 & .010 \\
\hline 製 造 & .843 & .862 & .019 & .288 & .268 & -.020 \\
\hline 卸 売, 小売 業 & .647 & .701 & .054 & .223 & .239 & .016 \\
\hline 運 輸, 通 信 業 & .893 & .906 & .013 & .034 & .041 & .007 \\
\hline 金融, 保隃,不動産業 & .968 & .960 & -.008 & .070 & .069 & -.001 \\
\hline 電気, ガス, 水道業 & .993 & .984 & -.009 & .007 & .007 & .000 \\
\hline サービス業 & .719 & .783 & .064 & .165 & .178 & .013 \\
\hline 務 & .992 & .985 & -.007 & .039 & .041 & .002 \\
\hline
\end{tabular}


ス・水道, 公務を除いて増加したが, 減少した産業の原 単位の差は 0.01 以下でわずかであった. 最も大きな増 加を示したのは漁・水産・養殖の 0.090 増, 続いて農, 林・狩橅, サービス, 卸売・小売で 0.05 以上の増加を 示した.このようにほぼ 0.01 以下の変動を示す鈗, 建 設，金融・保険・不動産，運輸・通信，電気・ガス・水 道, 公務の原単位はほぼ安定しているとみて差し支えな からう。また, 農・林・狩猟については原単位の変動は あるものの，原単位自体は低く，産業構成比も小さいの で原単位モデルに㧍いて原単位 $G$ の変動への寄与は小 さいと考えられ, 漁・水産・養殖については産業構成比 がきわめて小さいので $G$ への影響は小さい. 重要なの は製造, 卸売・小売, サービスの原単位の変動である.

\section{（3）原単位モデルの適合性}

1970 年のモデルの検定と同様に, 1975 年モデルの検 定は, 1975 年の産業別原単位の平均值（表一4）をモデ ル式の係数としておき，人口 10 万人以上 175 都市を対 象にモデルの適合性を調べたところ，パーセント RMS 誤差は $6.6 \%$ となり，1970 年モデルよりさらによい精 度を得る結果となった。実際值と推定值を図一8 に示 したが，全体として都市の推定值 $\left(Y^{*}\right)$ と実際值 $(Y)$ の隔たりは小さくなるとともに，推定值が実際值よりか なり低めにでていた吹田, 高槻, 茨木などの衛星型都市 も $\left|Y-Y^{*}\right|<0.1, \frac{Y^{*}}{Y}>0.9$ となり誤差が小さくなっ た.また，桐生，足利，一宮など推定原単位が大きくな る都市も誤差が小さくなった.

\section{（4）時間的安定性を考えたモデルの簡略化}

推定モデルが備えるべき性質として, 時間的一般性を 有し, 将来時点においても有効性を発揮できるという点

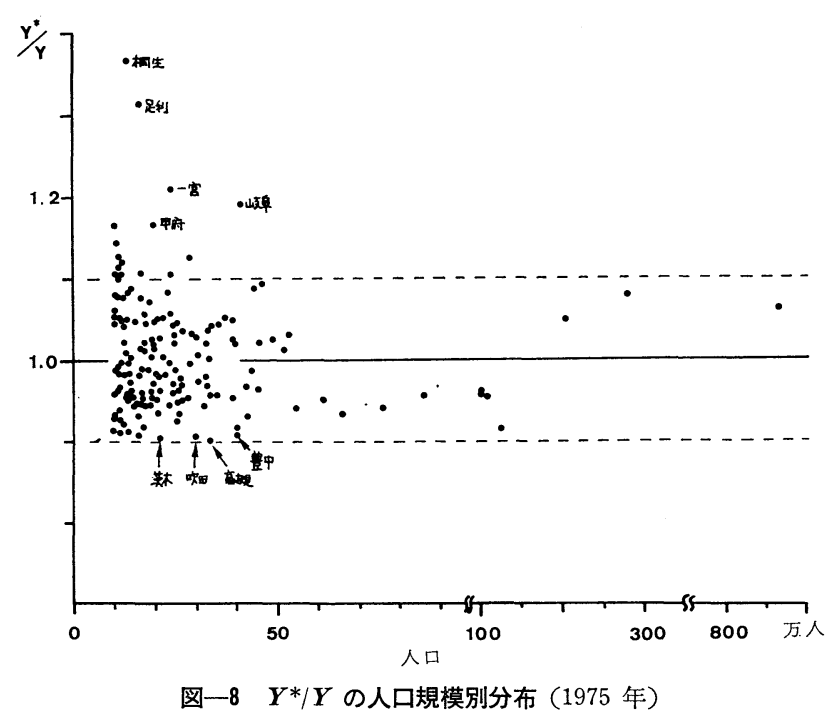

がまず挙げられる，続いて，空間的一般性，つまり，地 域の違いにかかわらず，モデルが共通して使えるといら こと，さらに，できるだけ簡単なモデルで時間的・空間 的一般性を具備していることが挙げられよう。このよう に推計モデルとしては, 時間的・空間的一般性, 簡略性 という3つの要素を具備していることが重要である.

本論文ではこれまでの 分析において，70 年と 75 年 で，それぞれの産業別原単位を導入したモデルにおい て, 時間断面 でのモデルの 復元性は 把握したのである が，時間的一般性の検討およびモデルの簡略化の試みは なされていない，そこで，5.(2) での産業別原単位の 70 年と 75 年の比較結果をもとに, 両年の原単位の差が 小さい産業については，両年で一定值をとるものとし， 差が大きいものについては，それぞれの時間断面での值 を使うものとし, 簡略化の試みとした. このとき, 時間 的に安定しているとする判断の目安として, 両年での原 単位の差が拉おむ衫 0.01 以下であるものとした。これ に該当する 産業は 表一5 より 鉱, 建設, 運輸・通信, 金融・保険・不動産, 電気・ガス・水道, 公務の 6 産業 であることが判明し た. また, 農・林・狩 猟, 漁・水産養殖は原 単位, 構成比とも低 $<$, 原単位 $G$ の変化 に及ぼす影響が小さい ので一定とおいても支 障がないとみなした。 そして, 70 年と 75 年 で共通した一定值をと るとみなしてよい産業 については, 両年の原

\begin{tabular}{|c|c|c|}
\hline \multirow{2}{*}{ 表一 } & \multicolumn{2}{|c|}{ 原 単 位 } \\
\hline & 70 年 & 75 年 \\
\hline 農, 林, 狩 畄 業 & \multicolumn{2}{|c|}{.100} \\
\hline 漁, 水産 養殖 業 & \multicolumn{2}{|c|}{.575} \\
\hline & \multicolumn{2}{|c|}{.910} \\
\hline 設 & \multicolumn{2}{|c|}{.795} \\
\hline 造 & .845 & .860 \\
\hline 卸 売, 小 売 業 & .645 & .700 \\
\hline 運輸, 通信 業 & \multicolumn{2}{|c|}{.900} \\
\hline 金融, 保険, 不動産業 & \multicolumn{2}{|c|}{.965} \\
\hline 電気, ガス, 水道業 & \multicolumn{2}{|c|}{.990} \\
\hline サーピス業 & \multirow{2}{*}{\multicolumn{2}{|c|}{$.720 \mid .785$}} \\
\hline 公 & & \\
\hline
\end{tabular}
単位の平均值をとり，小数点第 3 位を 5 で丸め た. 結果を 表一6 に示した. 製造, 卸売・小 売, サービスの 3 産業は構成比が高く, 原単位 の変動もあり，原単位 $G$ に及ぼす影響が大で あるので，両年別々に設定した．表一6 に示す 簡略化した産業別原単位を使用した原単位モデ ルの RMS 誤差は 1970 年で 7.6\%，1975 年 $6.5 \%$ となり, 予測精度は比較的よいことが判 明した。

\section{6. ま と め}

従来から指摘されているように安定した原単 位を求めることは困難であった．本研究では， なぜ原単位は変動するのかを解明することを最 初の問題認識とし, 基本的な社会発展の要因で 
ある産業構造, 特に就業構造によって原単位の変動を説 明することを試み，次に原単位の推計式を作成した。 こ れらの一連の研究過程の中で明らかにされた要点ををと めると次のようになる.

（1）原単位の変動を都市における就業構造の差異に より基本的に説明し得た．大きくは産業の発展段階を示 す $2+3$ 次産業構成比と正の比例関係にあることを, 時 間的, 空間的に示し得た.

（2）さらに都市の就業構造と原単位の関係を明らか にし, 原単位の推計式である原単位モデルを作成した. このモデルでは, 原単位は産業別原単位と産業別就業者 構成比の積で表現された。

（3）原単位モデルの係数である産業別原単位の安定 性を調べたところ, 製造業, 卸売・小売業, サービス業 を除いて安定していることが, 1970 年のみならず, 75 年においても示された.

（4）そして, 各時間断面で産業別原単位を都市の単 純平均值でもって示した原単位モデルの予測精度を RMS 誤差によりみたところ，1970 年で 7.4\%，75 年 で $6.6 \%$ となり, 比較的精度がよかった.

（5）さらに，70 年，75 年の産業別原単位の変化を 調べたところ, 製造業, 卸売・小売業, サービス業を除 いて, 時間的にも原単位が 安定していることが判明し た. 時間的に安定している産業については両年にわたり 同一值を設定し, 安定してない産業については両年の個 別值を用いた簡略化された原単位モデルの予測精度をみ たところ, RMS 誤差は 70 年 $7.6 \%, 75$ 年 $6.5 \%$ と なり簡略化しないモデルと同等の精度を示した。なお， 安定しなかった 3 産業いずれも時間的に原単位は増加し た.

今後の課題としては, 本研究で時間的, 空間的にも一 般性をもつ原単位推計式作成のための第一歩を行ったわ けであるが，今後，さらに時系列分析により原単位モデ ルの一般化を試みる必要がある. そのためには, 製造
業, 卸売・小売業, サービス業についての原単位の変動 構造を把握する必要があるように思われる. 最後に本研 究を進めるにあたり助力を願った大阪大学土木工学科学 生, 竹村英男氏 (現在, 建設技術研究所), 芋田晴夫氏 (現在，神戸市）ならびに 経済分野でのご助言をいただ いた大阪大学社会科学研究所教授, 筑井甚吉氏に謝意を 表する次第である.

\section{参 考 文 献}

1）米谷栄二・明神 証・溝畑靖雄: 交通需要発生の地域原 単位, 土木学会誌, Vol. 51, No. 6, 1966.

2）河上省吾 : 通勤・通学輸送需要の 予測について, 土木学 会論文報告集, No. 145, 1967.

3）黑川 洸：人の発生交通を中心とした諸都市活動の相互 関連に関する研究, 都市計画, No. 67, 1970.

4）黑川 洸：パーソントリップの発生特性に関する研究, 日本都市計画学会学術講演会論文集, 1969.

5）青山吉隆 : 大都市通勤交通の発生・集中および 分布の相 互関係について, 日本都市計画学会学術講演会論文集, 1969 .

6）清水浩志郎 : 通勤・通学交通の発生・集中原単位につい て, 土木学会第 31 回年次講演会概要集, 1976.

7）杉恵頼寧：交通需要モデルの 時間的移転可能性, 第 3 回 土木計画学研究発表会講演集, 1981 .

8) Kassoff, H. et al. : Trip Generation : A Critical Appraisal, Highway Research Record, No. 297, 1969.

9) Douglas, A.A. et al. : Trip generation techniques 1. Introduction, Traff. Engng. Control, Vol. 12, Nov., 1970.

10) Douglas, A.A. et al. : Trip generation techniques 2. Zonal Least-Squares Regression Analysis, Traff. Engng. Control, Vol. 12, No. 8, Dec. 1970.

11) Douglas, A.A. et al. : Trip generation techniques 3 . Household Least-Squares Regression Analysis, Traff. Engng. Control, Vol. 12, No. 9, Jan., 1971.

12) Douglas, A.A. et al. : Trip generation techniques 4 . Category Analysis and Summary of Trip Generation Techniques, Traff. Engng. Control, Vol. 12, No. 10, Feb., 1971.

13）経済審議会計量委員会: 計量委員会第 6 次報告 一新経済 社会 7 カ年計画のための多部門計量モデル—, 1980.

(1981.3.6 - 受付) 